Jurnal At-Tibyan: Jurnal Ilmu Alqur'an dan Tafsir Volume 6 No. 1, Juni 2021 (p. 59-80)

P ISSN 2442-594X | E ISSN 2579-5708

http://journal.iainlangsa.ac.id/index.php/tibyan

\title{
AL-QUR'ĀN MESSAGE ABOUT ETHOS OF WORK IN THE PANDEMIC TIME COVID-19
}

\author{
Eka Damayanti \\ Universitas Islam Negeri Alauddin Makassar, Indonesia \\ eka.damayanti@uin-alauddin.ac.id \\ Firdaus \\ Universitas Islam Negeri Alauddin Makassar, Indonesia \\ firdaus.malik@uin-alauddin.ac.id \\ Abdul Ghany \\ Universitas Islam Negeri Alauddin Makassar, Indonesia \\ abdul.ghany@uin-alauddin.ac.id \\ Ekawati Hamzah \\ Institut Agama Islam As'adiyah Sengkang, Indonesia \\ hamzahekawati@gmail.com \\ \begin{tabular}{|l|l|l|}
\hline \multicolumn{3}{|c|}{ DOI 10.32505/at-tibyan.v6i1.2420 } \\
\hline Submitted: 18-01-2021 & Revised: 13-04-2021 & Accepted: 29-05-2021 \\
\hline
\end{tabular}
}

\begin{abstract}
Al-Qur'ān is the holy book as a guide for people in any condition. This including the COVID-19 pandemic that has spread across the world. This article aims to outline the message in the Qur'ann about work ethic during the Covid-19 pandemic. This article is a literature review study with the Maudhui method of the Qur'ān verses related to work ethic. It was using content analysis. The study showed that even though the pandemic is taking place, Muslims are still obliged to work because Allah expressly commands them to work. God's commandment is that humans carry out work according to their ability and earnestly for life in the world and a provision in the hereafter because work is an act of jihad fisabillah.
\end{abstract}

Keywords: Work Ethic; Covid-19 pandemic; The message of the Qur'ān 


\begin{abstract}
Abstrak
Al-Qur'ān sebagai kitab suci terakhir memiliki arti penting sebagai pedoman umat manusia dalam berbagai kondisi apapun, termasuk dalam situasi pandemi covid-19 yang melanda dunia. Artikel ini bertujuan untuk mengurai pesan dalam al-Qur'ān tentang etos kerja di masa pandemi covid-19. Artikel dalam penelitian ini sebagai hasil dari penelitian literatur review dengan metode maudhui terhadap ayat-ayat al-Qur'ān yang berkaitan dengan etos kerja. Analisis menggunakan conten analisis. Hasil kajian menunjukkan meskipun pandemi berlangsung, umat Islam tetap wajib bekerja karena secara tegas Allah memerintahkan untuk bekerja. Perintah Allah agar manusia melaksanakan pekerjaan sesuai kemampuan dan dengan bersungguh-sungguh untuk kehidupan di dunia dan juga bekal di akhirat karena pada dasarnya bekerja merupakan perbuatan jihad fisabillah.
\end{abstract}

Key Words: Etos Kerja; Pandemi Covid-19; Pesan al-Qur'ān

\title{
Introduction
}

The covid 19 pandemic that has hit Indonesia and even the whole world since March 2020 has caused many major changes and even negative impacts. In deciding the transmission of covid-19, the government has imposed social distancing and even a lock down which requires restrictions on interaction between people. Activities that used to be done outside the home now have to be done inside the house. Workers do work from home (Work From Home). According to Fahri Abd Jalil and Sri Kasnelly ${ }^{1}$ during this pandemic, many workers were sent home for an unknown time, some were even dismissed from their permanent jobs.

The existence of restrictions on space for movement and layoffs of work have caused the community's economy to decline. Based on a survey research conducted in May 2020 in Makassar City by Eka Damayanti, et $\mathrm{al}^{2}$, there is evidence that the community has experienced a decrease in income during the Covid-19 pandemic. Of the 1,000 respondents, $75.2 \%$ had decreased incomes.

This declining income condition cannot be ignored. This will have the potential to have a worse impact ${ }^{3}$. Muslims in Indonesia and even throughout the world should find a spirit or work ethic as instructed in the al-Qur'ān and hadith. In addition, according to Asy'ari ${ }^{4}$, work can be seen as proof of human existence as Allah's creation on earth.

\footnotetext{
${ }^{1}$ Fahri Abd Jalil and Sri Kasnelly, "Meningkatnya Angka Pengangguran Di Tengah Pandemi (Covid19)," Al Mizan: Jurnal Ekonomi Syariah 3, no. 1 (2020): 45-60.

${ }^{2}$ Eka Damayanti, Ilhamsyah, Jamilah, and Taufiq Mathar, "Survei Persepsi Warga Kota Makassar Terhadap Tenaga Kesehatan," Laporan Penelitian (Makassar, May 2020).

${ }^{3}$ Wibowo Hadiwardoyo, "Kerugian Ekonomi Nasional Akibat Pandemi Covid-19," Baskara: Journal of Business \& Entrepreneurship 2, no. 2 (2020): 83-92

${ }^{4}$ Musa Asy’ari, Islam, Etos Kerja dan Pemberdayaan Ekonomi. Yogyakarta: Lesfi, 1997
} 
Al-Qur'ān is a holy book that was revealed to the Prophet Muhammad SAW as the last prophet and apostle which has an important meaning for mankind as a guide in every behavior. One of the contents in the Qur'ann contains the purpose of human creation, namely to worship and do good deeds. One form of human practice is in the form of work efforts to meet the necessities of life for himself and his family. There are many commands of religious texts both listed in the Qur'ān and in the hadiths that instruct mankind to work hard even under any circumstances.

There have been several previous studies that examined work ethic based on the Maudhui method, including those conducted by Sitepus, who wrote the Koran and alHadith, looking at the concept of work and how a Muslim behaves about work. In addition, Nur Kholis ${ }^{6}$ identifies verses in the Koran related to the work ethic which are summarized in three responsibilities, namely, responsibility towards God (Allah SWT), responsibility towards oneself, and responsibility towards others. .

Research conducted by Kamri, Ramlan, and Ibrahim $^{7}$ regarding work ethics according to the Qur'ān reveals that the Qur'ān regulates the fundamental values that are important for work, explaining specifically about work ethics in various verses. Sari Narulita ${ }^{8}$ concluded that there are a lot of religious texts both in the form of verses from the Qur'ān and hadith that encourage Muslims to have an optimal work ethic. In addition, Munir' in his research stated that there are several terms used by the Qur'ān in expressing the value of work, including 'Amal, Kasb, Juhd, Ibtigha, Sa'yu and Su'al.

Furthermore, Mohammad $\operatorname{Irham}^{10}$ stated that the way a person understands, lives, and practices the values of the Qur'ān and Al-Sunnah regarding the urge to work will shape the Islamic work ethic. Erwin Jusuf Thaib ${ }^{11}$ in his research stated that the Qur'ān and Sunnah not only regulate aspects of worship but also problems relating to work. Then Ahmad and Owoyemi ${ }^{12}$ who analyzed the concept of work ethic from the prophetic tradition revealed that work ethic is part of faith and has been emphasized by the Prophet Muhammad in many traditions.

Aan Najib ${ }^{13}$ also researched work ethic in the Qur'ān but focused on one chapter, namely Surah Saba, which revealed that there are eight verses in the surah that

\footnotetext{
5 Novi Indriyani Sitepu, “Etos Kerja Ditinjau Dari Perspektif Al-Qur'ān Dan Hadis," Jurnal Perspektif Ekonomi Darussalam 1, no. 2 (2015): 137-153.

${ }^{6}$ Nur Kholis, "Etos Kerja Islami," Jurnal Studi Islam (2008): 22-42.

7 Nor Azzah Kamri, Siti Ramlan, and Azharsyah Ibrahim, "Qur'ānic Work Ethics," Journal of Usuluddin 40 (2014): 135-172

${ }^{8}$ Sari Narulita, “Etos Kerja Dalam Islam,” Jurnal Studi Al-Qur'ān 4, no. 1 (2008): 46-60

9 Ahmad Munir, “Kerja Perspektif Al-Qur'ān,” Al-Tahrir 11, no. 1 (2011): 99-121

${ }^{10}$ Mohammad Irham, "Etos Kerja Dalam Perspektif Islam," Substantia: Jurnal Ilmu-Ilmu Ushuluddin 14, no. 1 (2012): 12-24.

${ }^{11}$ Erwin Jusuf Thaib, “Al-Qur'ān dan As-Sunnah Sebagai Sumber Inspirasi Etos Kerja Islami," Jurnal Dakwah Tabligh 15, no. 1 (2014): 1-9

${ }^{12}$ Ahmad and Owoyemi, "The Concept of Islamic Work Ethic: An Analysis of Some Salient Points in the Prophetic Tradition," International Journal of Business and Social Science 3, no. 20 (2012): 116123

13 Aan Najib, "The Value of Work Ethic in the Qur'ān Surah Saba'," International Journal of Humanities and Social Science 5, no. 3 (2015): 159-165
} 
motivate people to work hard in the world and be disciplined according to their professional fields. Then Muhammad Thariq Aziz ${ }^{14}$ conducted research showing that in Q.S Al-Quraish Allah has provided very short and concise guidelines regarding the issue of work ethic which if executed properly will bring prosperity to society or the country. The same thing was done by Budimansyah ${ }^{15}$ in his research which briefly examined the work ethic in Q.S Ar-Ra'd verse 11 and Q.S An-Najm verse 39, concluding that one of the Islamic work ethics is working hard.

From previous research, no articles have been found that discuss the importance of work ethic, especially during the Covid-19 pandemic. On this basis, this paper is written to describe the importance of a work ethic that is contained in the Qur'ān. The search that was carried out by the author was based on the Maudhui method of interpretation. Various interpretive methods have developed in this century, one of which is the maudhu'i method, which is then used in the discussion of this research in a structure ranging from the nature of work ethic, the form of work ethic to the discussion of the urgency of work ethic.

The maudhu'i exegesis method is a method that does not interpret the Koran as usual in an orderly manner with the Mushaf, but collects the verses of the Qur'ān with one particular theme and then interprets it $^{16}$. Mustafa Muslim defines this Maudhu'i method as a science that issues the meaning of understanding the Koran based on the purpose of several sets of verses in the same theme ${ }^{17}$. There are two forms of the maudhu'i (thematic) interpretation method. This study uses a thematic interpretation form by collecting related verses so that a holistic understanding can be achieved, the interpreter can avoid understanding the verse partially (in pieces).$^{18}$

The thematic method (mudhu'i) examines a problem in one field of science by grouping it into certain topics, or the themes contained in it. With this approach, research is directed to explore and discover the main trends that arise related to the issue of work ethic which is described in the Al-Qur'ān.

\section{The Essence of Work Ethic in The Qur'ān}

The word ethos which means "ethos" comes from a Greek word that means something that is believed, how to act, how to behave, and the perception of value. Work is an activity to do something. Work ethic is the spirit of work that characterizes

\footnotetext{
${ }^{14}$ uhammad Thariq Aziz, “Analisis Qur'ān Surah Al-Quraisy Tentang Etos Kerja," Tamaddun Jurnal Pendidikan dan Pemikiran Keagamaan 19, no. 1 (2018): 65-74

${ }^{15}$ Budimansyah, "Etos Kerja Dalam Al-Qur'ān," Al-Dzikra: Jurnal Studi Ilmu Al-Qur'ān dan AlHAdits 10, no. 2 (2016): 125-131.

${ }^{16}$ Fahd Abdur Rahman bin Sulaiman ar Rumi, Buhutzu Fi Ushul Al Tafsir Wa Manahijuhu (Riyadh: Maktabah at Taubah, t.t.), 62 .

${ }^{17}$ Musthafa Muslim, Mabahis Fi Tafsir Maudhu'i (Damaskus: Daar al Qalam, 1989), 16

${ }^{18}$ Several steps must be taken in the maudhu'i method: 1) determining the theme to be discussed, 2) collecting verses related to the theme of the discussion, 3) compiling a series of verses, 4) understanding the correlation of verses, 5) completing with the arguments. supporting evidence in the form of hadìs or ijma'. View in al Farmawi, al Bidayah Fi al Tafsir al Maudhu'I(Kairo: al hadarah al Arabiyyah, 1977), 63.
} 
and believes in a person ${ }^{19}$. In Arabic, work is called amala, kasaba, sa'yun / sa'a, wabtagū / ibtaga ${ }^{20}$

Work ethic is defined as characters and habits related to work that emanate from an attitude to life ${ }^{21}$. This becomes a basic attitude pattern that is ingrained and influences the behavior of life consistently and continuously. ${ }^{22}$ Work ethic is the soul or spirit of a person in carrying out tasks. If the spirit and spirit appear positive, it will be reflected by good performance and high value, for example working with joy and full of optimism ${ }^{23}$.

According to Sunardi ${ }^{24}$, a person's work ethic is closely related to their personality, behavior, and character. One of the things that can shape a person's personality and character is religious teachings. Furthermore, Anoraga and Prasetyo ${ }^{25}$ revealed that the Islamic work ethic comes from the Qur'ān and the hadith of the Prophet Muhammad. The same thing was also expressed by Indriani ${ }^{26}$ that the work ethic in Islam is closely related to the spirit of work which is expressed and implied in the Qur'ān and Al-Sunnah.

According to $\mathrm{Kirom}^{27}$, every Muslim person who has a work ethic that is by the demands of the Qur'ān and Al-Hadith is one form of implementing the work ethic in Islam. According to Sono, Hakim, and Oktaviani ${ }^{28}$, the Islamic work ethic includes characteristics that describe how humans should work in an organization. Mashur Malaka $^{29}$ mentioned the characteristics of an Islamic work ethic, including professionalism, diligence, honest, trustworthiness, and creativity. In addition, Sohari ${ }^{30}$ in his research stated that the characteristics of the Islamic work ethic were explored and formulated based on the concept of faith as a foundation and good deeds as a form

\footnotetext{
${ }^{19}$ Tim Penulis, Kamus Besar Bahasa Indonesia (Jakarta: Balai Pustaka, 2007), 309.

${ }^{20}$ hmad Warson Munawwir, al-Munawwir Kamus Arab - Indonesia, Cet. XIV (Surabaya: Pustaka Progressif, 1997), 973.

${ }^{21}$ Ahmad Janan Asifuddin, Etos Kerja Islami, (Surakarta: Muhammadiyah University Press, 2007), 27.

${ }^{22}$ M. Dawam Rahardjo, Islam dan Transformasi Sosial-Ekonomi (Jakarta: Lembaga Studi Agama dan Filsafat, 1999), 251

${ }^{23}$ Amir Hamzah, Etos Kerja Guru Era Industri 4.O. (Malang: Literasi Nusantara, 2020), 40

${ }^{24}$ Didi Sunardi, “Etos Kerja Islami,” JISI UMJ: Jurnal Integrasi Sistem Industri 1, no. 1 (2014)

${ }^{25}$ Bhirawa Anoraga and Ari Prasetyo, "Motivasi Kerja Islam dan Etos Kerja Islam Karyawan Bank Jatim Syariah Cabang Surabaya," JESTT2, no. 7 (2015): 531-541

26 Weni Indriani, "Kontribusi Etos Kerja Islami Trehadap Kinerja Dosen," El-Idare: Jurnal Manajemen Pendidikan Islam 1, no. 2 (2016): 173-188

${ }^{27}$ Cihwanul Kirom, "Etos Kerja dalam Islam," Tawazun: Journal of Sharia Economic Law 1, no. 1 (2018): 57-72

${ }^{28}$ Nanda Hidayan Sono, Lukman Hakim, and Lusi Oktaviani, "Etos Kerja Islam Sebagai Upaya Meningkatkan Kinerja," Prosiding Seminar Nasional dan Call For Paper Ekonomi dan Bisnis (2017): 411-420.

${ }^{29}$ Mashur Malaka, “Etos Kerja Dalam Islam,” Al- Munzir 6, no. 1 (2013): 55-62.

${ }^{30}$ Sohari, "Etos Kerja Dalam Perspektif Islam," ISLAMICONOMIC: Jurnal Ekonomi Islam 4, no. 2 (2013): 1-24.
} 
built on it. If a person's work ethic is weak, it will result in weak professional ethics in the body of Muslims ${ }^{31}$.

Work ethic in Islam is considered not only to earn a living but also as a form of worship. An Islamic work ethic is a form of the Muslim belief that work is an implementation of his life goal, namely to gain the pleasure of $\mathrm{Allah}^{32}$. The Islamic work ethic must be possessed by Muslims as a serious effort by moving all their assets, thoughts, and remembrance to actualize or place their meaning as a servant of Allah Almighty and to position themselves as part of the best society (khairu al-ummah) ${ }^{33}$. Islamic work ethic can be seen in the behavior of working honestly and responsibly, being trustworthy, always keeping promises, tolerating others, always guarding the mouth against being envious of others, and avoiding slander. ${ }^{34}$

According to Solihin ${ }^{35}$, in his study of the Work Ethic in an Islamic Perspective, it is revealed that Islam views work ethic as a noble thing, even Islam places it as a form of worship. The same thing was also expressed by Kholis ${ }^{36}$ that Islam places work in a very noble and noble place, which is classified as fi sabilillah. In addition, Pulungan ${ }^{37}$ explained that the Qur'ān encourages humans to prosper the world, making effort the principle to gain sustenance in life.

The author looks for verses about work ethics based on the classification of several pronunciations including عَّلَ (amala) which means work, the pronunciation and its various derivations in the Koran are found in many places ${ }^{38}$, but those related to work ethics directly, contained in QS al-Taubah / 9: 105, QS al-Zumar / 39: 39. In

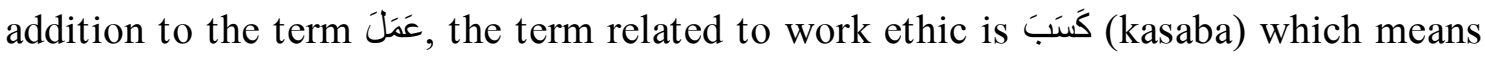
work and effort, some of the verses that mention this pronunciation include QS alBaqarah / 2: $134^{39}$. سَعْى (sa'yun) in the Koran contains the meaning of effort and earnest is contained in several verses including QS al-Isra '/ 17: 19, QS al-Najm / 53: 39-40) ${ }^{40}$.

${ }^{31}$ Iman S Hidayat, "Etos Kerja Sesuai Dengan Etika Profesi Islam," MIMBAR : Jurnal Sosial dan Pembangunan 22, no. 1 (2006): 130-142.

${ }^{32}$ Nurcholish Majid, Islam Agama Kemanusiaan: Membangun Tradisi dan Visi Baru Islam Indonesia (Jakarta: Paramadina, 1995), 216.

${ }^{33}$ Toto Tasmara, Etos Kerja Pribadi Muslim (Jakarta: Dana Bakti Waqaf, 1995), 79

${ }^{34}$ Izzudin al-Khatib at-Tamimi, Nilai Kerja dalam Islam (Jakarta: CV. Pustaka Mantiq, 1992), 79.

${ }^{35}$ M Solihin, “Etos Kerja Dalam Perspektif Islam,” Jurnal Manajerial 4, no. 1 (2005): 9-16

${ }^{36}$ Nur Kholis, "Etos Kerja Dalam Perspektif Islam," Al-Mawarid Journal of Islamic Law XI (2004): $142-157$

${ }^{37}$ Sahmiar Pulungan, "Etos Kerja Dan Etika Profesi Dalam Pandangan Islam," Wahana Inovasi 3, no. 2 (2014): 512-519

${ }^{38}$ Pronunciation can be founded in several place in the Qur'ān: QS Al Baqarah: 277; QS Yunus: 9; QS Hud: 23, 46; QS Al Kahfi: 20, 107; QS Maryam: 96; QS Luqman: 8; QS Fushilat: 8, QS Al Buruj: 11; QS Al Bayyinah: 7; QS An Nisa: 123, 124, QS Thoha: 112; QS At Tahrim: 11; QS Fatir: 10; QS At Taubah: 60, 105; QS Az Zumar: 39. View in al Raghib al Ashfahani, Mu'jam Mufradat Al Fadzil Qur'ān (Beirut: Daar al fikr, n.d.), 661.

${ }^{39}$ Pronunciation كَنَبَ can be founded in several place in the Qur'ān: QS Al Baqarah : 79, 81, 134, 201, 202, 264, 267, 281, 286; QS Al An'am: 158; QS Ibrahim: 18; as Syura: 22; al An'am: 70, 120, 164; at Tawbah: 82; QS Fathir: 45; QS al Imran: 161; QS An Nisa: 32; QS al Anfal: 28. View in al Raghib al Ashfahani, Mu'jam Mufradat Al Fadzil Qur'ān (Beirut: Daar al fikr, n.d.), 681.

${ }^{40}$ Pronunciation ${ }^{2}$ can be founded in several place in the Qur'ān: QS al baqarah: 114, 205; QS at Tahrim: 8; QS al Maidah: 33, 64; QS an Najm: 40, QS al Lail: 4; QS al Isra': 19; QS al Anbiya': 94; QS 
وَابنَغُوْ (wabtagū) in the verse of the Qur'ān shows a serious effort to seek and take something that has been provided by Allah for his creatures. As in QS al-Jumu'ah / 62: 10, QS al-Qashas / 28: 73, QS al-Qashas / 28: 77.

\section{'Amala (kerja).}

The author identifies the work ethic verse based on the pronunciation words (amala, kasaba, sa'yun / sa'a, wabtagū / ibtaga) to find verses that are relevant to the theme of work ethic during the Covid-19 pandemic as follows:

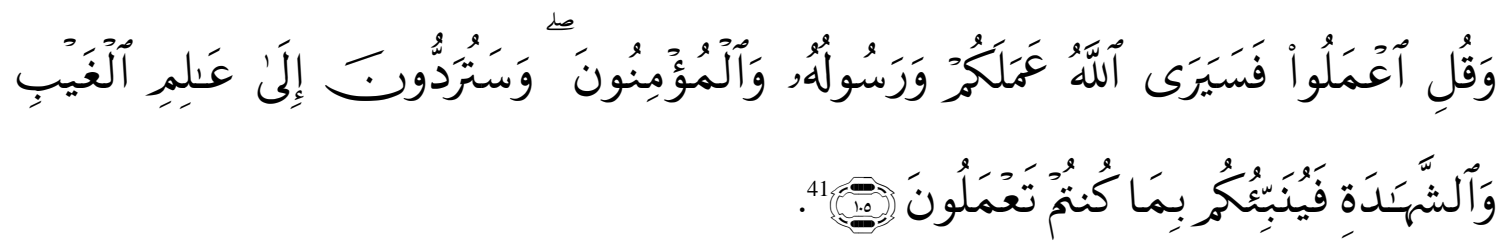

Translation : "And Say: "Work you, then Allah and His Messenger and the believers will see your work, and you will be returned to (Allah) who knows what is unseen and what is real, then He will tell you what you have done. do it. " (QS. Al-Taubah [9]: 105).

This verse intends to instruct people to always work, Allah does not limit it only to the believers, but for every human being, if they can make their life prosperous with effort and hard work. This verse motivates so that every human being should always do good, work sincerely because that action will be seen and seen quite clearly.

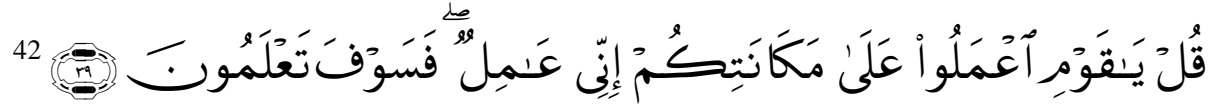

Translation: "Say:" O my people, work according to your circumstances I will work (also), then someday you will know ". (QS. Al-Zumar [39]: 39)

The two verses above use the word amal which means practical action. The word al-amal is the word most frequently mentioned in the Qur'ān, namely the discovery of the word 'amal (' amal, 'amilu, ta'malun, ya'malun, and others) in the Qur'ān which is mentioned 360 times. Especially for the perpetrator, 'human deeds are called 312 verses. Actions include good deeds ('amil as-salihat) and bad actions (amil as-

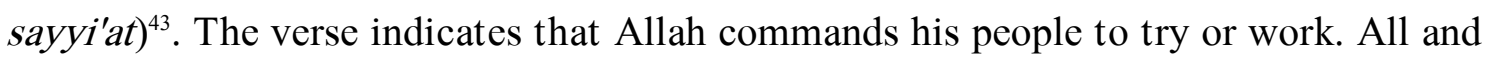
every effort will be known by Allah, the Messenger of Allah, and the believers. Every effort made in the future will be assessed and get a reply according to the effort. Every good or bad deed in the hereafter will be clearly shown as it is, both hidden and visible.

al Shaffat: 102; QS al Hajj: 51; QS Saba': 5, View in al Raghib al Ashfahani, Mu'jam Mufradat Al Fadzil Qur'ān (Beirut: Daar al fikr, n.d.), 636.

${ }^{41}$ Departemen Agama RI, al-Qur'ān dan Terjemahnya, (Jakarta: CV Darus Sunnah, 2002), 204

${ }^{42}$ Departemen Agama RI, al-Qur'ān., 463.

${ }^{43}$ Novi Indriyani Sitepu, "Etos Kerja Ditinjau Dari Perspektif Al-Qur'ān Dan Hadis," Jurnal Perspektif Ekonomi Darussalam 1, no. 2 (2015): 137-153. 10.24815/jped.v1i2.6550 


\section{Kasaba (work and business).}

The word (kasaba) in the Qur'ān is mentioned 67 times in 27 chapters and 60 verses. Kasaba in the Koran means work and effort. The word Kasab implies wanting, seeking, doing, and obtaining, from here the meaning of looking for sustenance and looking for anything that is beneficial emerges ${ }^{44}$. As in QS al-Baqarah / 2: 134 .



Translation: "That is the past people; for him what he has worked for and for you what you have worked for, and you will not be held accountable for what they have done "(QS. Al-Baqarah [2]: 134).

\section{Sa'yun / sa'a (effort and earnest).}

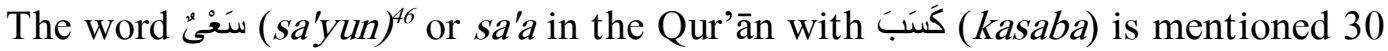
times spread over 20 surahs and 26 verses $^{47}$. Sa'yun also means walking quickly and then developing its meaning so that it is used in the sense of earnest effort and the need for seriousness in trying to achieve what you want and aspire to. As-sa'yun in alQur'ān contains the meaning of effort and earnest as in Surah al-Isra / 17: 19

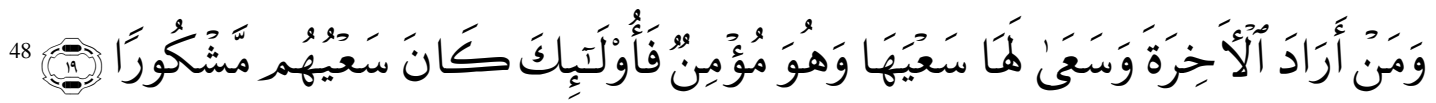

Translation: "And whoever wants the afterlife and strives in that direction seriously while he is a believer, then they are people whose efforts are rewarded well" (QS. Al-Isra '[17]: 19)

The word al-sa'yun is also found in QS al-Najm / 53: 39-40

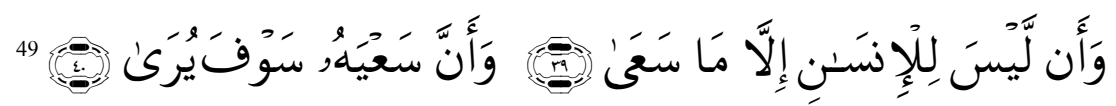

Translation: "And that a man gets nothing but what he has worked for. And that the effort will be seen (to him). " (QS. Al-Najm [53]: 39-40)

Thus this verse underscores the need for seriousness in trying to achieve what one wants and aspires to.

\footnotetext{
${ }^{44}$ Sitepu, “Etos Kerja Ditinjau Dari Perspektif Al-Qur'ān Dan Hadis, 141

${ }^{45}$ Departeman Agama RI, Al-Qur'ān dan Terjemahnya, 21.

46 Novi Indriyani Sitepu, "Etos Kerja Ditinjau Dari Perspektif Al-Qur'ān Dan Hadis," Jurnal Perspektif Ekonomi Darussalam 1, no. 2 (2015): 137-153. 10.24815/jped.v1i2.6550

${ }^{47}$ M. Quraish Shihab, Tafsir Al-Misbah, Vol. II. (Tanggerang: Lentera Hati, 2016), 54

${ }^{48}$ Departeman Agama RI, Al-Qur'ān dan Terjemahnya, 285.

${ }^{49}$ Departeman Agama RI, Al-Qur'ān dan Terjemahnya, 528.
} 


\section{Wabtagū / ibtaga (seeking and taking something that Allah has provided for his creatures).}

The word وَابْنَغُو (Wabtagū) or ibtaga comes from the word يَبْغنى بَغَى is mentioned in the al-Qur'ān 31 times spread over 16 surahs and 23 verses. The word وَابْنَغُو (Wabtagū) in the Qur'ān implies seeking. According to linguists, it means wanting, looking for, doing, wanting, and getting. The word وَابنَغَوْ (wabtagū) in the verse of the Koran denotes a serious effort to seek and take something that has been provided by Allah for his creatures. As in QS al-Jumu'ah / 62: 10, QS al-Qashas / 28: 73, QS al-Qashas / 28: 77.



Translation: "When the prayers have been fulfilled, then you will be scattered on the face of the earth; and seek the gift of Allah and remember Allah a lot so that you may be lucky. " (QS. Al-Jumu'ah [62]: 10)

This verse encourages every Muslim to be scattered on the face of the earth to earn a living and actively work to optimize all aspects that are useful for the needs of society. After they perform prayers and do their activities, they should keep doing dhikr at work, always remembering Allah. So that his efforts are maintained in a way that is justified by Allah and does not harm others, as well as to get the gifts, advantages, and virtues that come from Allah. ${ }^{51}$

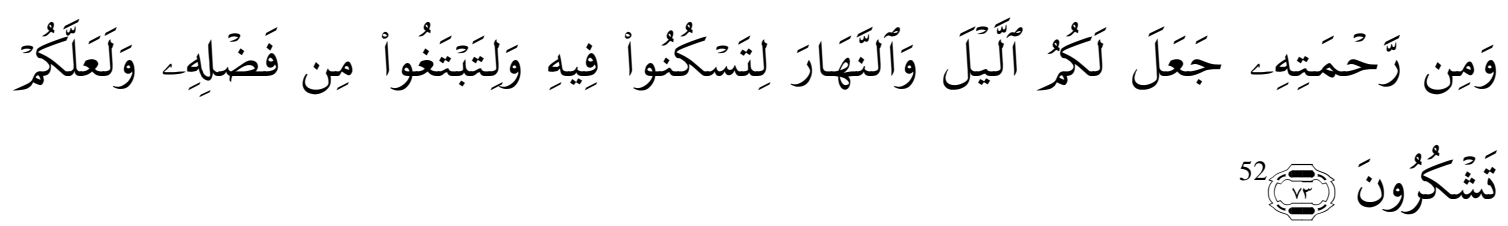

Translation: "And because of His mercy, He made for you night and day, so that you may rest that night and that you may seek some of His grace (during the day) and that you may give thanks to Him". (QS. Al-Qashas [28]: 73).

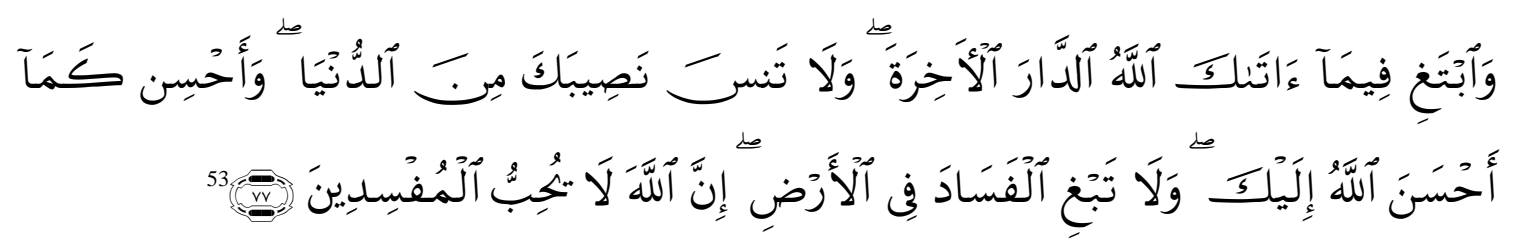

Translation: "And look for what Allah gives you (happiness) in the land of the hereafter, and do not forget your share of the (enjoyment) of the world

\footnotetext{
${ }^{50}$ Departeman Agama RI, Al-Qur'ān dan Terjemahnya,., 555.

${ }^{51}$ M. Quraish Shihab, Wawasan al-Qur'ān (Bandung: Mizan, 1995), 403

${ }^{52}$ Departemen Agama RI, Al-Qur'ān dan Terjemahnya, 395.

${ }^{53}$ Departeman Agama RI, Al-Qur'ān dan Terjemahnya,. 395
} 
and do good (to others) as Allah has done good to you, and do not do damage to the (face) of the earth. Indeed, Allah does not like those who do damage ". (QS. Al-Qashas [28]: 77).

The above verse implies God's teaching that must be held as a reference for humans in navigating the ark of life, namely the teaching of the rules of life balance. The goal is that humans in orienting their activities in the afterlife are not apathetic towards worldly affairs ${ }^{54}$. This shows that the interests of life in the hereafter and the interests of life in the world are of equal importance. Humans are encouraged to balance the two.

Based on the search for the essence of the work ethic based on the words amala, kasaba, sa'yun / sa'a, wabtagu / ibtaga, it can be concluded that the work ethic in the Koran is a useful work or work done by humans seriously for what Allah has already done. provide on earth for mankind so that humans are lucky, grateful, and become their provisions in the hereafter.

\section{The Work Ethic Form in the Qur'ān}

The advice of the Qur'ān to work

Allah's command for mankind to work can be seen in QS al-Taubah / 9: 105

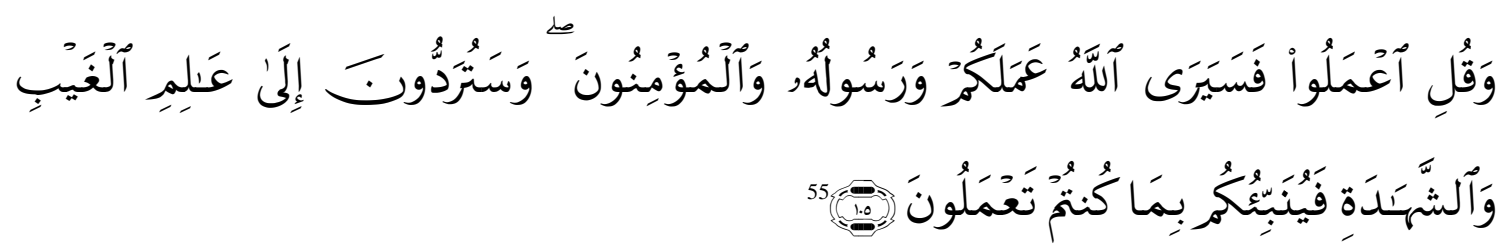

Translation: "And say:" Work you, then Allah and His Messenger and the believers will see your work, and you will be returned to (Allah) who knows what is unseen and what is real, and He will tell you what you have done. do it. " (QS. Al-Taubah [9]: 105).

Quraish Shihab in his interpretation explains that the verse contains an order to work for you because Allah is sole with various pious and useful deeds, both for yourself and others or the general public. Allah will see, that is, judge and reward your deeds. And His Messenger and the believers will see and judge as well, then adjust their treatment with your needs, and then you will be returned to Allah through death. Allah knows the unseen and what is real, then you will be told the sanctions and rewards for what you have done, both what appears to the surface and what you hide in your heart. ${ }^{56}$

According to Imam Al-Razi in QS Al-Taubah / 9: 105 it contains everything a believer needs regarding religion, world, life, and the hereafter. From the wording in the verse, two things are illustrated: on the one hand, there is a targhib tone

\footnotetext{
${ }^{54}$ Sayyid Qutb, Fi Zilal al-Qur'ān, Jilid III (Beirut: Dar al-Fikr, n.d.), 2711

${ }^{55}$ Departeman Agama RI, Al-Qur'ān Dan Terjemahnya, 204.

${ }^{56}$ M. Quraish Shihab, Tafsir Al-Misbah, Vol. II. (Tanggerang: Lentera Hati, 2016), 237
} 
(encouragement) for those who are obedient, and on the other side a tarhib tone (threat) appears for those who commit immoral acts. That is, you are serious about doing something for your future because all your actions will get their rights in this world and the hereafter. In the world, this action will be witnessed by Allah, His Messenger, and the believers. If it is in the form of obedience, he will get great praise and reward in this world and the hereafter. However, if it is in the form of disobedience, he will get humiliation in this world and painful torment in the hereafter. ${ }^{57}$

Surah al-Taubah verse 105 commands everyone and everyone to do business, including economic ventures. All and every effort will be known by Allah, Rasulullah saw. and believers, in this case, inform the importance of the judgment of Allah, the assessment of His Messenger, and the assessment of the believers of the performance (work) of a person. All these achievements will receive good rewards/results related to worldly work performance (economic motive) and those related to ukhrawi values. All and every action of a person, good or bad in the afterlife, will be informed and shown transparently as it is, both hidden and visible.

In the hadis narrated by Ahmad bin Hanbal, the Messenger of Allah said: "Neither one of you can eat food which Allah Azzawajalla loves more than the food that results from the efforts of his two hands." This hadith encourages Muslims to work hard, as the Holy Prophet gave an example of how Prophet David AS was. He as a prophet and king tried with his own hands to provide for his life and his family. Likewise with the Prophet Muhammad, as a caliph and a Prophet, he worked with his own hands to make ends meet and even help other people.

According to Imam Nawawi, the opinion of the scholars about the meaning of the hadith is something that is done with one's own hands. If the hand business is agriculture then that is the best possible business, because everything contains its efforts $^{58}$. Hadith is also to emphasize the nobility of people who use their hands and abilities. So even though the Covid 19 pandemic conditions, you still have to work on your own hands.

\section{How to apply the work ethic according to the Qur'ān}

In the al-Qur'ān QS al-Furqan / 25: 47 it has been explained that during the day to work and to work while at night so that people use it to rest. So allow humanity to work during the day. Even in another verse in QS al-Mulk / 67: 15 Allah frees mankind to explore the earth in search of lawful sustenance.

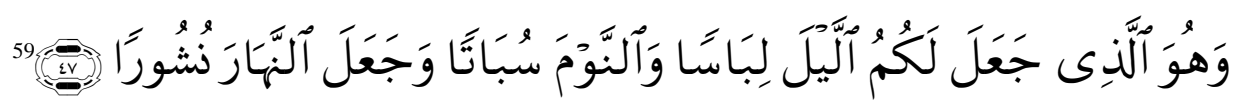

\footnotetext{
${ }^{57}$ Imam Ar-Razi, Mafatihul Ghaib, Juz 16 Cet. III. (Bairut: Dar Ihya al-Turasi al-Arabiy, 1994), 141

58 Mokhtar Bukhari, Penelitian Pendidikan Dan Pendidikan Islam Di Indonesia (Jakarta: IKIP Muhammadiyah Press, 1994), 194.

${ }^{59}$ Departemen Agama RI, al-Qur'ān dan Terjemahnya, 364.
} 
Translation: "He is the one who makes for you the night (as) clothes and sleeps to rest. And he made the day to wake up trying. " (QS. Al-Furqan [25]: 47).

The interpretation of the above verse is to stop doing activities to rest the body because the limbs will get tired due to the many activities they do scattering around during the day to make a living. If it is nighttime and he stays, these various activities stop and rest, then sleep is achieved, which is resting for the body and spirit together. And he made the day to wake up to try" people were scattered at that time for their life, trade, and business. ${ }^{60}$



Translation: "He is the one who made the earth easy to explore, so explore in all its directions and eat a portion of His sustenance. And only to Him will you (return after) be resurrected". (QS. Al-Mulk [67]: 15).

The interpretation of the above verse is to travel anywhere you want from all parts of it and scatter you in all its directions to carry out various kinds of business and trade. And know that your efforts will not benefit you at all unless Allah makes it easy for you. Therefore, he said رِزْقِهِ مِنْ وَكُلُوا "and eat part of His sustenance". Thus, the effort is a means in no way contradicting tawakkal. ${ }^{62}$

Humans are encouraged to seek sustenance and seek whatever is beneficial. As in QS al-Baqarah / 2: 134.

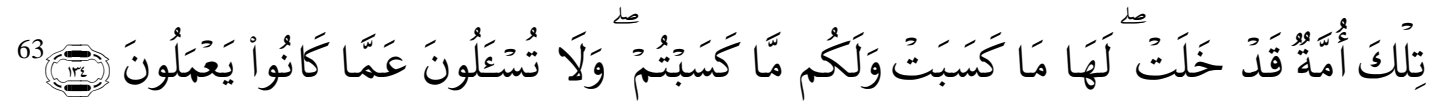

Translation: "That is the past people; for him what he has worked for and for you what you have worked for, and you will not be held accountable for what they have done "(QS. Al-Baqarah [2]:134)

The work or effort carried out by humans is also explained by Allah Almighty that it must be by one's abilities. Allah says in QS Al-Zumar / 39: 39 regarding orders to carry out work according to their respective abilities and capacities:

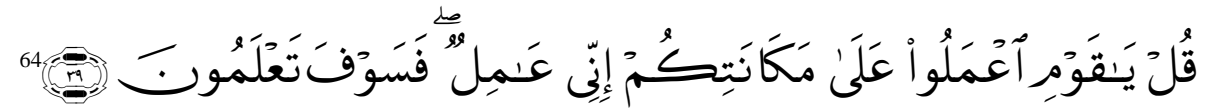

Translation: "Say:" O my people, work according to your circumstances I will work (also), then someday you will know ". (QS. Al-Zumar [39]: 39).

${ }^{60}$ Abdullah bin Muhammad bin Abdurrahman bin Ishaq Al-Sheikh and Lababut Tafsir Min Ibnu Katsir, "Tafsir Ibnu Katsir," in Terj. M. Abdul Ghoffar Dan Abu Ihsan Al-Atsari, Juz 16 Cet. I. (Kairo: Pustaka Imam asy-Syafi'i, 2004), 117.

${ }^{61}$ Departeman Agama RI, Al-Qur'ān dan Terjemahnya, 563.

${ }^{62}$ Abdullah bin Muhammad bin Abdurrahman bin Ishaq Al-Sheikh and Lababut Tafsir Min Ibnu Katsir, "Tafsir Ibnu Katsir," Terj. M. Abdul Ghoffar Dan Abu Ihsan Al-Atsari, Juz 16 Cet. I. (Kairo: Pustaka Imam asy-Syafi'i, 2004), 242

${ }^{63}$ Departeman Agama RI, Al-Qur'ān dan Terjemahnya, 21.

${ }^{64}$ Departeman Agama RI, Al-Qur'ān dan Terjemahnya, 436. 
Al-Maraghi interpreted, that Allah gave orders to His Messenger, "Say (Muhammad) to your people who are stubborn and are not aware of Allah's orders," if they are not aware and still do not believe in the word of Allah through my message, then do what? what you want, and do whatever you want, "I will keep doing everything that Allah has commanded me. Each of you will know who will get the punishment and punishment from Allah who insulted you and who you will suffer for eternity. Only to Allah is the place of trust for those who surrender and ask for His guidance and protection. ${ }^{65}$

In the above verse, the Quraish Shihab interprets that the position of the Prophet Muhammad is clear, there are several groups of the Prophet's people who raise and do not hear the order, they are infidels, and some of these people are also believers, in the verses of al- The Qur'ān provides evidence of the heresy of the disbelievers where they continue to commit disobedience, Allah said to the Messenger of Allah, that says (Muhammad) to them (unbelievers and believers): O my people, namely family, friends and those who live with me, work hard, that is work istiqamah everything you want to achieve according to your ability, circumstances and way of life, as well as I, work hard in various forms of positive activities according to the abilities and methods taught by Allah, someday you will know who gets the punishment from Allah who humiliates him in this world and the hereafter. ${ }^{66}$

In this verse, although it is aimed at challenging the disbelievers, the message contained in the verse implies that a high work ethic means doing work according to one's abilities or circumstances. Will have fatal consequences if doing the job is not on his expertise. Humans were created by their respective talents and expertise, so with this provision, humans are expected to be able to prosper this earth as well as possible.

\section{The form of work ethic in the Qur'ān}

The form of work ethic in the Koran can be seen in Allah's command to mankind to carry out work seriously to achieve what they want and aspire to as in QS al-Isra 1/ 17: 19 and QS al-Najm. / 53: 39-40.

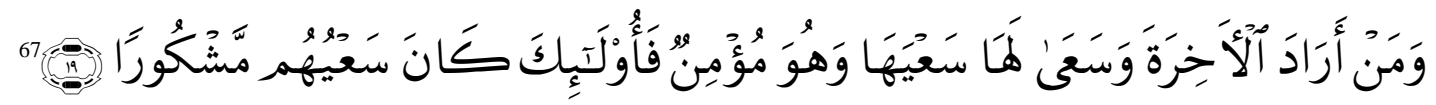

Translation: "And whoever wants the afterlife and strives in that direction seriously while he is a believer, then they are people whose efforts are rewarded well" (QS. Al-Isra '[17]: 19).

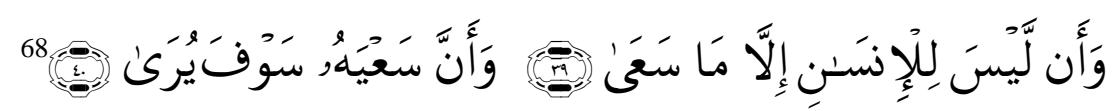

\footnotetext{
${ }^{65}$ Ahmad Mustafa Al-Maraghi, Tafsir Al-Maraghi, Juz 24 (Semarang: Toha Putra, 1987), 13

${ }^{66}$ M. Quraish Shihab, Tafsir Al-Misbah, Vol. II (Jakarta: Lentera Hati, 2016), 503

${ }^{67}$ Departeman Agama RI, Al-Qur'ān dan Terjemahnya, 285.

${ }^{68}$ Ibid., 528.
} 
Translation: "And that a man gets nothing but what he has worked for. And that the effort will be seen (to him)." (QS. Al-Najm [53]: 39-40).

Quraish Shihab through the interpretation of Al-Misbah said that a servant who wants happiness in the afterlife, must make efforts with a strong faith and with high sincerity and be able to go through the tests that Allah has given. The measure of faith is not only in speech but is manifested in the form of practice in everyday life. Those who only hope for worldly happiness will make their efforts and hard work only on worldly things. So even though it is known that the end of the world will come tomorrow, he will no longer make efforts for the hereafter. However, those who always hope for worldly happiness and the hereafter will always work until the end of their lives even though the end of tomorrow has arrived. Because for him what is worked on in the world will also be obtained in the hereafter. ${ }^{69}$

As in the hadith of the Prophet Muhammad that "If one of you does something, then do it diligently." These verses and hadiths underline the need for seriousness in trying to achieve what you want and aspire to. Even though the Covid-19 pandemic should still be filled with a form of work ethic as a serious endeavour with full persistence. Apart from making serious efforts, he is instructed to keep praying and pray earnestly to Allah Almighty to avoid any difficulties and disasters. Regarding balancing the affairs of the world and the hereafter, according to the arguments based on the previous scholars quoted by al-Qurthubi in his commentary book, which means: "Work for your world as if you will live forever, and do good for your hereafter as if you are going to die. tomorrow". ${ }^{70}$

The Prophet Muhammad SAW never gave an example of his people to wait for gifts to meet the needs of life, the Prophet strongly denounced laziness. Therefore, as a devout Muslim, he should not only expect and wait for government assistance during this pandemic. Life continues even during the Covid-19 outbreak, humans are required to continue to increase their efforts to meet their daily needs, without having to become weak humans who are just waiting for a helping hand from various parties.

\section{The Urgency of Work Ethic in the Qur'ān}

\section{Work in the world for provisions in the hereafter}

Allah's command to mankind to work in the world is a provision for the afterlife, as Allah has mentioned in the letter al-Qashash / 28: 77;



\footnotetext{
${ }^{69}$ M. Quraish Shihab, Tafsir Al-Misbah, Vol. II (Jakarta: Lentera Hati, 2016), 54-55.

${ }^{70}$ Syaikh Imam Al-Qurthubi, Tafsir Al-Qurthubi, Juz 13 (Jakarta: Pustaka Adzam, 2009), 800-802

${ }^{71}$ Departemen Agama RI, Al-Qur'ān dan Terjemahnya, 395.
} 
Translation: "And look for what Allah gives you (happiness) in the land of the hereafter, and do not forget your share of the (enjoyment) of the world and do good (to others) as Allah has done good to you, and do not do damage to the (face) of the earth. Indeed, Allah does not like those who do damage ". (QS. Al-Qashas [28]: 77)

Al-Tabary in its interpretation reveals the meaning of وَابْتَغُو ا contained in (QS alJumu'ah / 62: 10, QS al-Qashas / 28: 73, 77) is to find a suitable time and place in trying to open or produce the gift of Allah. which is still stored for the sake of life in this world and the hereafter ${ }^{72}$. In the narration of Abdul Ibn Hamid Ibn Qatada ra, he said "let you seek (sustenance) which Allah allows because it is your right". ${ }^{73}$ As Ibn Arabi said, quoted by Hamka in his book of commentary al-Azhar which reminded "Do not forget your part (right) in the world, namely lawful property". ${ }^{74}$

The interpretation of the above verse according to al-Maraghi, is that Allah commands to be scattered on earth to take care of all the interests of life in the world after there is an order to carry out useful affairs for the hereafter. In trying (both for the benefit of the world and the hereafter) one should always remember Allah's muraqabah (supervision) of humans in every way. It also states that you should not leave the pleasures of the world, from matters of eating, drinking, clothing, and living quarters. Since God has rights over you and you have rights over you, so does your family. Use these treasures and favors to obey your god and get closer to Him with various deeds that can lead you to the acquisition of rewards in this world and the hereafter. ${ }^{75}$

Allah always commands servants to continue to work and strive so that the interests of worldly and spiritual affairs run and are fulfilled in a balanced manner. People should not only pursue worldly things, and forget about the afterlife, and vice versa. There should be a balance between the life of this world and the hereafter. AlQur'ān teaches humans how important it is to create balance in themselves and human life, this is in the form of intellectual balance and conscience, body and spirit, as well as the balance of the world and the hereafter.

So based on the above verse, it can be concluded that working in the world must always be based on the intention of worshiping Allah so that work will get blessings and become provisions in the afterlife. So Muslims still have to work hard even during the Covid-19 period by still implementing health protocols.

\section{Work as a source of livelihood}

Having a high work ethic is very important for the continuation of human life. Based on the search for the same work ethic theme, the writer found QS An Naba / 78: 11.

\footnotetext{
${ }^{72}$ Abi Ja'far Muhammad bin Jarir al Thabary, “Jami’ Al Bayan An Ta’wil Ayyi Al-Qur'ān,” Juz XII, Jilid VIII. (Beirut: Dar al-Fikr, n.d.), 144.

${ }^{73}$ Abdu al-rahman Jalaluddin Al-Suyuthi, “Al Dar Al Ma’tsur Fi Tafsir Al Ma’tsur,” Jiid VI (Beirut: Dar al-Fikr, n.d.), 139

${ }^{74}$ Hamka, Tafsir Al-Azhar, Juz XXX. (Jakarta: PT. Pembimbing Masa, 1970), 128

75 Ahmad Mustafa Al-Maragi, “Tafsir Al-Maraghi” (Mesir: Mustafa Al Baby Al Halaby, 1874), 94
} 


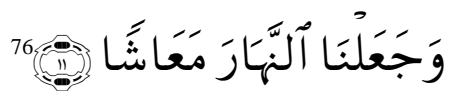

Translation: "And we have made it a day to make a living" (QS. An Naba [78]: 11)

In the book, Tafsir al-Azhar explains verse 11 of QS An-Naba "'And We have made it a day to earn a living." Through the night to unwind and get tired, when the morning the soul and body are healthy and refreshed. Then with fresh body and soul scattered on the face of the earth with effort and hard work, gathering sustenance, earning a living, and drinking. Then that's ma'aasya; livelihood. In another form, it is also called ma'iisyah. ${ }^{77}$

Islam instructs its adherents to make an effort (try) in this casework, be diligent, diligent, tenacious, and earnest in doing a job. Those who have the desire to try, work hard, and are truly promised by Allah Almighty will have a successful life, both in this world and in the hereafter. The Word of Allah swt. in Surah Al-Insyirā ḥ / 94: 7

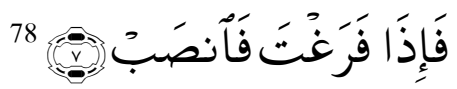

Translation: "So when you have finished (of a business), do seriously (business) other". (QS. Al-Insyirā ḥ [94]: 7)

M. Quraish Shihab interpreted the QS. Al-Insyirā h / 94: 7 "if you are already in a situation (after you were busy), then (work) until you are tired, or raise it (a new problem). The content of the verse indicates that a person must always be busy. When a job has ended, then you have to start another job again. This verse gives a message that a Muslim does not know the time to take things easy. ${ }^{79}$

The same thing is expressed by Hamka that the above verse contains a message that "if a job has been completed or a plan has become a reality, then fans ab, which means prepare to start a new job. With the awareness that all the work that has been completed or that you are about to start again is not free from difficulties, but in that difficulty, ease will also come along. There will be any inspiration that Allah will give you, as long as the Muslim community always relies all your work on faith ". ${ }^{80}$

As Allah says in Surah Ar-Ra'ad / 13: 11.



\footnotetext{
${ }^{76}$ Departeman Agama RI, Al-Qur'ān Dan Terjemahnya, 583.

${ }^{77}$ Hamka, Tafsir Al-Azhar, Juz 30. (Jakarta: Pustaka Panji Mas, 1983), 4

${ }^{78}$ Departemen Agama RI, Al-Qur'ān Dan Terjemahnya, Cet I (al-Madinah al-Munawwarah: Mujamma' al-Malik Fahd li Tiba'at al-Mushaf, $1418 \mathrm{H}), 1073$.

${ }_{79}$ M. Quraish Shihab, Tafsir Al-Qur'ān Al-Karim: Tafsir Atas Surah-Surah Pendek Berdasarkan Urutan Turunnya Wahyu, Cet I (Jakarta: Pustaka Hidayah, 1997), 463-464

${ }^{80}$ Hamka, Tafsir Al-Azhar, Juz XXX. (Jakarta: PT. Pembimbing Masa, 1970), 199

${ }^{81}$ Departemen Agama RI, Al-Qur'ān dan Terjemahnya, 250.
} 
Translation: "For humans, there are angels who always follow him in turn, in front of and behind him, they are guarding him by the command of Allah. Indeed, Allah does not change the condition of a people so that they change the condition that is in themselves. And if Allah wants something bad for a people, then no one can refuse it; and sometimes there is no protector for them but Him ". (QS. Ar-Ra'ad [13]: 11)

The verse above illustrates that Allah Almighty will not change the fate of a people or group of people if they do not try to change it, therefore, the spirit to try, in this case, work ethic is needed to change the fate of every individual or group. Because this has been confirmed in the interpretation of this verse, that Allah will repay all human deeds, good and bad, according to what he has tried. The nature of a high work ethic can produce something lawful, blessed by Allah, is blessed, and has many good benefits in the world, especially in the hereafter. There is no reason for humans not to try or not to work despite the pandemic, on the contrary, high morale needs to be improved so that the standard of human life is better than before. As long as they are still living, humans are required to remain enthusiastic at work so that they can carry on their lives in a good way and are blessed by Allah SWT.

Work as an effort to seek God's gifts so that people are lucky

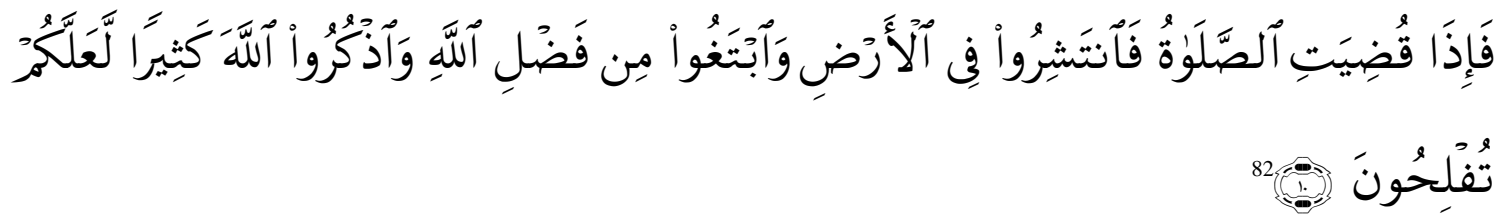

Translation: "When the prayers have been fulfilled, then you will be scattered on the face of the earth; and seek the gift of Allah and remember Allah a lot so that you may be lucky. " (QS. Al-Jumu'ah [62]: 10)

This verse encourages every Muslim to be scattered on the face of the earth to earn a living and actively work to optimize all aspects that are useful for the needs of society. After they perform prayers and do their activities, they should keep doing dhikr at work, always remembering Allah. So that his efforts are maintained in a way that is justified by Allah and does not harm others, as well as to get the gifts, advantages, and virtues that come from Allah. ${ }^{83}$

This verse implies that after people have finished worshiping Allah (prayer), then they are ordered to spread out on the face of the earth to carry out their worldly affairs, and they always try to find good and lawful sustenance after humans have fulfilled their obligations regarding the afterlife, then every servant should remember Allah. as much as possible in doing his business in a manner that is good and not cheating, does

\footnotetext{
${ }^{82}$ Departemen Agama RI, Al-Qur'ān dan Terjemahnya, 555

${ }^{83}$ M. Quraish Shihab, Wawasan Al-Qur'ān (Bandung: Mizan, 1995), 403
} 
not commit fraud, and does not work for lies. At the end of the verse, Allah reminds His servants that He Knows everything real and hidden.



Translation: "And because of His mercy, He made for you night and day, so that you may rest that night and that you may seek some of His grace (during the day) and that you may give thanks to Him". (QS. Al-Qashas [28]: 73).

Another urgency of work ethic is that people are grateful that it can be seen in the above verse. In Tafsir Ibn Katsir (And because of His mercy) the mercy of Allah SWT. (He made it for you night and day so that you rest on him) that is at night (and so that you may seek some of His gifts) during the day, to make a living by traveling, visiting, activities and activities (and so that you are grateful. ) with Allah's blessings at both times, namely at night and during the day. ${ }^{85}$

It can be understood that the meaning of the above verse is that among the blessings that Allah SWT has given to humans, namely by making it night and day alternately so that every creature can take advantage of these two conditions, take shelter and rest from being tired at night and seek fortune by working. at noon. And so that you thank Allah for every blessing given. The giving of humans time to look for fortune by working which is symbolized by the time of day, is a thing that shows, indeed Allah SWT does not want a servant to be lazy and stand idle, Allah suggests that each of His servants always has the spirit of life actively working to achieve social welfare, both individuals and the ummah, and as the culmination of the servant's efforts, it is accompanied by gratitude towards the creator.

\section{Conclusion}

The description in the discussion section can be concluded that work ethic is a concept that can be found in the Qur'ān which is traced based on the Maudhui method. Based on the words amala, kasaba, sa'yun / sa'a, wabtagū / ibtaga, it can be concluded that the work ethic in the Koran is a useful work or work done by humans seriously for what Allah has provided on earth for the people. humans so that humans are lucky, grateful, and become their provisions in the hereafter. The work ethic in the Qur'ân can be seen in the Qur'ānic advice to work, how to apply the work ethic in the form of working during the day by studying the corners of the earth by looking for useful

\footnotetext{
${ }^{84}$ Departemen Agama RI, Al-Qur'ān dan Terjemahnya, 395.

${ }^{85}$ Abdullah bin Muhammad bin Abdurrahman bin Ishaq Al-Sheikh and Lababut Tafsir Min Ibnu Katsir, "Tafsir Ibnu Katsir," Terj. M. Abdul Ghoffar Dan Abu Ihsan Al-Atsari, Juz 16 Cet. I. (Kairo: Pustaka Imam asy-Syafi'i, 2004), 295
} 
sustenance. Work must be following the expertise to prosper the earth. The form of work ethic is in the form of working with sincerity or persistence. As for the urgency of the work ethic, namely working solely not for the world alone but as a provision in the hereafter, working as a source of livelihood, working as an effort to seek God's gifts so that people are lucky, and working as an effort to seek God's gifts so that people can thank Him

From the findings in the discussion, the results of this paper imply for Muslims to continue to work hard despite the conditions of the COVID-19 pandemic. Work relying on their own hands and is based on expertise to make the most of the resources possible. Apart from that in doing work, Muslims must do it seriously and with great diligence. The most important thing is that working in the world must always be based on the intention of worshiping Allah so that work will be blessed and become a provision in the afterlife because work is an act of jihad fisabillah.

\section{REFERENCES}

Abdurrahman. Fathul Kabir Fii Dhammi Ziyadah Ila Jaami'u Al-Shagir. Juz 1. Lebanon: Dar al-Fikri, 2003.

Ahmad, and Owoyemi. "The Concept of Islamic Work Ethic: An Analysis of Some

Salient Points in the Prophetic Tradition." International Journal of Business and

Social Science 3, no. 20 (2012): 116-123. https://ijbssnet.com/journals/ Vol_3_No_20_Special_Issue_October_2012/12.pdf.

Al-Maraghi, Ahmad Mustafa. Tafsir Al-Maraghi. Juz 24. Semarang: Toha Putra, 1987.

Al-Maragi, Ahmad Mustafa. "Tafsir Al-Maraghi." Mesir: Mustafa Al Baby Al Halaby, 1874.

Al-Naisābūriy, Muslim bin al-Ḥajjāj Abū al-Hasan al-Qusyairiy. Al-Musnad Al-Ṣahīḥ Al-Muḱtaṣār Bi Naqli Al- 'Adli 'an Al-'Adl Ilā Saw. Juz II. Bairut: Dār Ihyā alTurāṣ al-'Arabiy, n.d.

Al-Qurthubi, Syaikh Imam. Tafsir Al-Qurthubi. Jakarta: Pustaka Adzam, 2009.

Al-Sheikh, Abdullah bin Muhammad bin Abdurrahman bin Ishaq, and Lababut Tafsir

Min Ibnu Katsir. "Tafsir Ibnu Katsir." In Terj. M. Abdul Ghoffar Dan Abu Ihsan Al-Atsari. Cet. I. Kairo: Pustaka Imam asy-Syafi'i, 2004.

Al-Suyuthi, Abdu al-rahman Jalaluddin. "Al Dar Al Ma'tsur Fi Tafsir Al Ma'tsur."

Beirut: Dar al-Fikr, n.d.

Al-Syaibani, Abu'Abdillah Ahmad bin Muhammad bin Hanbal bin Hilal bin Asad.

Musnad Al-Imam Ahmad Bin Hanbal. Juz 8. Cet. Beirut: Muassasat al-Risalah, 2001.

Anoraga, Bhirawa, and Ari Prasetyo. "Motivasi Kerja Islam Dan Etos Kerja Islam 
Karyawan Bank Jatim Syariah Cabang Surabaya.” JESTT 2, no. 7 (2015): 531541.

Ar-Razi, Imam. Mafatihul Ghaib. Cet. III. Bairut: Dar Ihya al-Turasi al-Arabiy, 1994. Ashfahani, al Raghib al. Mu'jam Mufradat Al Fadzil Qur'ān. Beirut: Daar al fikr, n.d.

Asifuddin, Ahmad Janan. Etos Kerja Islami. Surakarta: Muhammadiyah University Press, 2007.

Asy'ari, Musa. Islam, Etos Kerja Dan Pemberdayaan Ekonomi. Yogyakarta: Lesfi, 1997.

At-Tamimi, Izzudin al-Khatib. Nilai Kerja Dalam Islam. Jakarta: CV. Pustaka Mantiq, 1992.

Ayyub, Sulaiman bin Ahmad bin. Mu'jam Kabir Li Thabrani. Juz 19. Ce. Beirut: Maktabah Ibnu Taymiyah, 1994.

Aziz, Muhammad Thariq. “Analisis Qur'ān Surah Al-Quraisy Tentang Etos Kerja." Tamaddun Jurnal Pendidikan dan Pemikiran Keagamaan 19, no. 1 (2018): 65-74.

Budimansyah. "Etos Kerja Dalam Al-Qur'ān.” Al-Dzikra: Jurnal Studi Ilmu Al-Qur'ān dan Al-HAdits 10, no. 2 (2016): 125-131.

Bukhari, Mokhtar. Penelitian Pendidikan Dan Pendidikan Islam Di Indonesia. Jakarta: IKIP Muhammadiyah Press, 1994.

Damayanti, E., Ilhamsyah, Jamilah, and Taufiq Mathar. "Survei Persepsi Warga Kota Makassar Terhadap Tenaga Kesehatan." Laporan Penelitian. Makassar, May 2020.

Departeman Agama RI. Al-Qur'ān Dan Terjemahnya. Cet I. al-Madinah alMunawwarah: Mujamma' al-Malik Fahd li Tiba'at al-Mushaf, n.d.

Departemen Agama RI. Al-Qur'ān Dan Terjemahnya. Jakarta: CV Darus Sunnah, 2002.

Farmawi, Al. Al Bidayah Fi Al Tafsir Al Maudhu'I. Kairo: al hadarah al Arabiyyah, 1977.

Hadiwardoyo, Wibowo. "Kerugian Ekonomi Nasional Akibat Pandemi Covid-19." Baskara: Journal of Business \& Entrepreneurship 2, no. 2 (2020): 83-92.

Hamka. Tafsir Al-Azhar. Juz XXX. Jakarta: PT. Pembimbing Masa, 1970. - Tafsir Al-Azhar. Juz 30. Jakarta: Pustaka Panji Mas, 1983.

Hamzah, Amir. Etos Kerja Guru Era Industri 4.0. Malang: Literasi Nusantara, 2020.

Hidayat, Iman S. "Etos Kerja Sesuai Dengan Etika Profesi Islam." MIMBAR : Jurnal Sosial dan Pembangunan 22, no. 1 (2006): 130-142.

Indriani, Weni. "Kontribusi Etos Kerja Islami Trehadap Kinerja Dosen.” El-Idare: Jurnal Manajemen Pendidikan Islam 1, no. 2 (2016): 173-188. http://jurnal.radenfatah.ac.id/index.php/El-idare/article/view/675.

Irham, Mohammad. "Etos Kerja Dalam Perspektif Islam.” Substantia: Jurnal Ilmu-Ilmu Ushuluddin 14, no. 1 (2012): 12-24.

Jalil, Fahri Abd, and Sri Kasnelly. "Meningkatnya Angka Pengangguran Di Tengah Pandemi (Covid-19).” Al Mizan: Jurnal Ekonomi Syariah 3, no. 1 (2020): 45-60. 
http://ejournal.annadwahkualat ungkal.ac.id/index.php/almizan/article/view/142.

Kamri, Nor Azzah, Siti Ramlan, and Azharsyah Ibrahim. "Qur'ānic Work Ethics." Journal of Usuluddin 40 (2014): 135-172. https://ssrn.com/abstract=2687422.

Kholis, Nur. "Etos Kerja Dalam Perspektif Islam." Al-Mawarid Journal of Islamic Law XI (2004): 142-157.

—. "Etos Kerja Islami." Jurnal Studi Islam (2008): 22-42.

Kirom, Cihwanul. "Etos Kerja Dalam Islam.” Tawazun: Journal of Sharia Economic Law 1, no. 1 (2018): 57-72.

Majid, Nurcholish. Islam Agama Kemanusiaan: Membangun Tradisi Dan Visi Baru Islam Indonesia. Jakarta: Paramadina, 1995.

Malaka, Mashur. "Etos Kerja Dalam Islam.” Al- Munzir 6, no. 1 (2013): 55-62.

Munawwir, Ahmad Warson. Al-Munawwir Kamus Arab - Indonesia. Cet. XIV. Surabaya: Pustaka Progressif, 1997.

Munir, Ahmad. "Kerja Perspektif Al-Qur'ān.” Al-Tahrir 11, no. 1 (2011): 99-121.

Muslim, Musthafa. Mabahis Fi Tafsir Maudhu'I. Damaskus: Daar al Qalam, 1989.

Najib, Aan. "The Value of Work Ethic in the Qur'ān Surah Saba'." International Journal of Humanities and Social Science 5, no. 3 (2015): 159-165. http://www.ijhssnet.com/journals/Vol_5_No_3_March_2015/21.pdf.

Narulita, Sari. “Etos Kerja Dalam Islam.” Jurnal Studi Al-Qur'ān 4, no. 1 (2008): 4660. http://journal.unj.ac.id/unj/index.php/jsq/article/view/2411.

Pulungan, Sahmiar. "Etos Kerja Dan Etika Profesi Dalam Pandangan Islam." Wahana Inovasi 3, no. 2 (2014): 512-519.

Qutb, Sayyid. Fi Zilal Al-Qur'ān. Jilid III. Beirut: Dar al-Fikr, n.d.

Rahardjo, M. Dawam. Islam Dan Transformasi Sosial-Ekonomi. Jakarta: Lembaga Studi Agama dan Filsafat, 1999.

Rumi, Fahd Abdur Rahman bin Sulaiman ar. Buhutzu Fi Ushul Al Tafsir Wa Manahijuhu. Riyadh: Maktabah at Taubah, n.d.

Shihab, M. Quraish. Tafsir Al-Misbah. Vol. II. Tanggerang: Lentera Hati, 2016. . Tafsir Al-Qur'ān Al-Karim: Tafsir Atas Surah-Surah Pendek Berdasarkan Urutan Turunnya Wahyu. Cet I. Jakarta: Pustaka Hidayah, 1997.

- Wawasan Al-Qur'ān. Bandung: Mizan, 1995.

Sitepu, Novi Indriyani. “Etos Kerja Ditinjau Dari Perspektif Al-Qur'ān Dan Hadis.” Jurnal Perspektif Ekonomi Darussalam 1, no. 2 (2015): 137-153.

Sohari. "Etos Kerja Dalam Perspektif Islam." ISLAMICONOMIC: Jurnal Ekonomi Islam 4, no. 2 (2013): 1-24.

Solihin, M. “Etos Kerja Dalam Perspektif Islam.” Jurnal Manajerial 4, no. 1 (2005): 916.

Sono, Nanda Hidayan, Lukman Hakim, and Lusi Oktaviani. "Etos Kerja Islam Sebagai Upaya Meningkatkan Kinerja." Prosiding Seminar Nasional dan Call For Paper Ekonomi dan Bisnis (2017): 411-420. https://jurnal.unej.ac.id/index.php/ prosiding/article/view/6687. 
80 Al-Qur'ān message about ethos of work in The pandemic time covid 19 - Eka Damayanti et al.

Sunardi, Didi. "Etos Kerja Islami." JISI UMJ: Jurnal Integrasi Sistem Industri 1, no. 1 (2014).

Tasmara, Toto. Etos Kerja Pribadi Muslim. Jakarta: Dana Bakti Waqaf, 1995.

Thabary, Abi Ja'far Muhammad bin Jarir al. "Jami’ Al Bayan An Ta'wil Ayyi AlQur'ān.” In Juz XII. Jilid VIII. Beirut: Dar al-Fikr, n.d.

Thaib, Erwin Jusuf. “Al-Qur'ān dan As-Sunnah Sebagai Sumber Inspirasi Etos Kerja Islami." Jurnal Dakwah Tabligh 15, no. 1 (2014): 1-9.

Tim Penulis. Kamus Besar Bahasa Indonesia. Jakarta: Balai Pustaka, 2007. 